УДК 373.3.091.312

DOI:

Наталія Винницька, кандидат педагогічних наук, старший викладач кафедри математики, інформатики та методики їх викладання у початковій школі Дрогобииького державного педагогічного університету імені Івана Франка

\title{
ЗАСТОСУВАННЯ ГРУПОВОЇ ТА КОЛЕКТИВНОЇ ФОРМ НАВЧАННЯ НА УРОКАХ У ПОЧАТКОВІЙ ШКОЛІ
}

У даній статті систематизовано особливості використання та організачії групової і колективної форм роботи на уроках у початковій школі.Виокремлено такі форми навчальної діяльності учнів на занятті, як фронтальна, індивідуальна, групова та колективна, їх ефективність у проведенні занять з математики та інформатики. Зокрема описано недоліки та переваги кожної з них. Описано методичні особливості організації групової та колективної форм роботи під час вивчення початкового курсу математики і інформатики. Проаналізовано особливості поєднання різних форм навчання.

Ключові слова: початкова школа; форми навчальної діяльності: групова, індивідуальна, фронтальна, колективна, математика, інформатика.

Jim. 8.

Nataliya Vynnytska, Ph.D.(Pedagogy), Senior Lecturer of the Mathematics, Computer Science and Teaching Methods at Elementary School Department Drohobych Ivan Franko State Pedagogical University

\section{FEATURES OF THE USE OF GROUPAND COLLECTIVE TEACHING FORMS AT PRIMARY SCHOOL}

The teacher's activity is extremely multiform. He has to solve a whole set of tasks of the education, upbringing and development of pupils every day and every lesson. The complexity of the teacher's work is caused not only by the wide range of tasks but also it depends on the variability and uniqueness of interaction with pupils that makes impossible any universal solution of pedagogical situations. It is well known that mechanical imitation of colleague's lesson into another class or lesson (even if it is a very good lesson) may be extremely unsuccessful.

The teacher should purposefully choose the best version for construction of the educational process to ensure the most effective solution of elementary tasks in a specific environment. Improvement the methodology of the realization of the lesson is the most important direction of the increase the quality of education and upbringing of the rising generation. At the same time, the teachers' professional knowledge and ability to evaluate the quality of their work further to improve the methodology of the realization of the lesson.

They distinguish the following basic forms of schoolchildren's learning activities at the lesson as frontal, individual and group ones. These forms run through the whole educational process and contain all its components. They differ in the number of pupils and ways of work organization. Unfortunately, the teachers of primary school not always effectively use a certain form of learning organization, they do not aware and study its specificity. As a result, it usually essentially reduces the quality of the given educational material and the pupils' knowledge.

In the article we have systematically revealed the features of the use and organization of group and collective forms of work at the lessons at primary school. We have distinguished such forms of pupils' educational activity at the lesson as frontal, individual, group and collective ones; we have shown their effectiveness in the conduction of Mathematics and Computer Science lessons. In particular, the disadvantages and advantages of each of them are described. Methodical peculiarities of the organization of group and collective forms of work in the process of studying of the initial course of Mathematics and Computer Science are distinguished. The peculiarities of the combination of different teaching forms are analyzed.

Keywords: an elementary school; forms of educational activity: group, individual, frontal, collective, mathematics, informatics.

П остановка проблеми. Вчитель - це надзвичайно багатогранна особистість. Кожен день вона розв'язус безліч завдань щодо виховання та розвитку своїх учнів. Праця вчителя дуже не легка, вона складається не лише широким спектром завдань, а й мінливістю взаємодії зі школярами, яка унеможливлює якийсь один універсальний розв'язок педагогічних ситуацій.
Ми знаємо, що механічне відтворювання навіть дуже вдалого уроку в другому класі чи уроку іншого вчителя може бути невдалим.

Щоб забезпечити найбільш ефективне вирішення початкових завдань, вчитель повинен цілеспрямовано вибрати найкращий варіант побудови навчання. Відшліфовування методів проведення уроку $є$ пріоритетним напрямком 


\section{ЗАСТОСУВАННЯ ГРУПОВОЇ ТА КОЛЕКТИВНОЇ ФОРМ НАВЧАННЯ}

НА УРОКАХ У ПОЧАТКОВІЙ ШКОЛІ

покращення якості навчання, виховання, творчого розвитку особистості. Тобто, звідси випливає, чим більше вчитель володіє професійними знаннями і вміннями, тим краще відбувається урок.

Розрізняють основні форми навчальної діяльності учнів на уроці: фронтальна, індивідуальна та групова. Вони охоплюють все навчання і містять усі його компоненти. Ці форми відрізняються кількістю учнів та способами організації роботи. На жаль, не завжди буває так, що вчителі початкових класів ефективно використовують певну форму організації навчання, вони не усвідомлюють і не вивчають їх специфіки, що зазвичай суттєво знижує якість поданого матеріалу та знань учнів.

Аналіз останніх досліджень і публікацій. Докорінна зміна сучасної освіти в інформаційному суспільстві удосконалює процес виховання та розвитку дитини, підкреслюючи їі гуманізацію. Особистісно-орієнтоване навчання зосереджує його організацію на основі поваги до кожного учня 3 урахуванням його індивідуального розвитку, трактування його як свідомого відповідального суб'єкта навчально-виховної взаємодії.

Навчання цецілеспрямована передача та засвоєння певного досвіду, що здійснюється за допомогою різної кількості способів. Суть такої реалізації визначається конкретною формою навчання. Категорія “форма навчання” є однією з головних у дидактиці, але іiі тлумачення все ще не має повної єдності між дослідниками. Так, М.М. Скаткін, І.Я. Лернер та В.К. Дяченко визначають форми навчання загальні (фронтальні, групові, індивідуальні) та конкретні (урок, семінар, виїзд тощо). Дослідники Ю.І. Бурлак та В.О. Вихрущ виділяють узагальнене поняття “форма організації навчання” за родами - “форма навчальної діяльності учнів” [1], Ю.І. Мальований тлумачить “форми навчальної діяльності учнів на занятті” як одну зі складових змісту категорії “форми навчання" [5].

Вчитель - це творча особистість, яка творить протягом всієї своєї педагогічної діяльності. Вона потребує вдосконалення і накопичення своїх знань і умінь, але основною вимогою - йти в ногу 3 часом. Тому всі вчителі повиннівикористовувати на своїх уроках інноваційні технології навчання, які внесуть новизну у формі подачі нового навчального матеріалу, допоможуть дітям краще його засвоїти.

Для якісного оновлення ходу уроку вчитель повинен організовувати так навчальну діяльність учнів, щоб врахувати їх готовність і зміст навчання. Саме це особливо впливає на результати навчання, розвиток особистості, емоції та почуття.
Досвід вчителів початкових класів показав, що саме групова та колективна робота найкраще допомагає розвивати навички спілкування учнів. Але слід розрізняти “діяльність в колективі” і “колективну діяльність”. Колективна діяльність дітей на перших етапах є формальною. Групова робота - це насамперед гра, гра в організацію, гра в навчання. Гра допомагає учням зрозуміти тему теми, знайти незрозуміле.

Оскільки групові форми навчальної діяльності відкривають для дітей великі можливості для співпраці, спілкування та глибокого пізнання навколишнього середовища, вони стали предметом психолого-педагогічного дослідження.

Цікаво, що групова форма навчання виникла як альтернатива нинішнім традиційним дидактичним методам. Він базувався на ідеях Ж.-Ж. Руссо, Дж. Г. Песталоцці та Дж. Дьюї про вільний розвиток та виховання дитини. Свого часу Песталоцці стверджував, що вміле поєднання індивідуальних та групових навчальних занять сприяє успішному засвоєнню дітьми нових знань, а активність та самодіяльність учнів підвищують ефективність уроку. Таким чином виникла ідея взаємного навчання, висловлена Дж. Песталоцці.

Значний внесок у розвиток теорії групового навчання внесли французькі педагоги К. Гарсія, С. Френе, Р. Галь, Р. Кузіне, польські дослідники В. Окунь, Р. Петриківський, Ч. Куписєвич та багато інших зарубіжних вчених.

У 70-х роках XX ст. важливим напрямом дослідження загальних форм навчання була навчально-пізнавальна діяльність учнів в умовах колективної, групової, індивідуальної роботи на уроці (А.М. Алексєюк, Ю.К. Бабанський, І.Я. Лернер, Х.Й. Лійметс та ін.)

Останні два десятиліття найбільше виник інтерес до цих форм навчальної діяльності. Вагомим внеском у розробку загальних принципів організації групової навчальної діяльності можна вважати дослідження В.К. Дяченка, В.В. Котова, Г.О. Цукермана, О.Г. Ярошенка та інших. Дидактичні основи організації групового навчання молодших школярів висвітленіу роботах В.О. Вихрущ, Є.С. Задої, І.М. Вітковський та К.Ф. Нор [3].

Метою статті $\epsilon$ виявлення та систематизація особливостей організації групових та колективних форм роботи, їх ефективності у проведенні занять 3 математики, інформатики в початковій школі.

Виклад основного матеріалу. Форма організації навчання - це спосіб упорядкування навчальної діяльності, що регулюється певними заздалегідь визначеними правилами; зовнішне вираження узгодженої діяльності викладача та учнів, що здійснюється за певними принципами та режимами. 


\section{ЗАСТОСУВАННЯ ГРУПОВОЇ ТА КОЛЕКТИВНОЇ ФОРМ НАВЧАННЯ НА УРОКАХ У ПОЧАТКОВІЙ ШКОЛІ}

Поширеними формами організації виховної роботи $€$ колективні (уроки в школі, лекції та семінари, екскурсії, факультативні заняття тощо) та індивідуальні (самостійна робота, дипломні та курсові проекти тощо), які суттєво відрізняються за ступенем самостійності діяльності учнів та ступеня керівництва навчальною діяльністю викладачем.

Як ми вже наголошували, навчальні заходи в класі охоплюють фронтальні, індивідуальні та групові заняття. Вони є основою всього навчального процесу. 3'ясуємо суть та особливості групової навчальної діяльності учнів, порівнявши ії з колективною.

Розглядаючи фронтову роботу, необхідно підкреслити ії обмежені можливості здійснення навчального спілкування учнів. Це можливо лише 3 дозволу вчителя, його ініціативи та в незначній мірі [7, 15].

Для індивідуальної роботи кожен студент працює самостійно; темп його роботи визначається ступенем власної цілеспрямованості, розвитку інтересів і схильностей, освітніх можливостей, готовності тощо. Індивідуальна навчальна діяльність не передбачає безпосередньої взаємодії учнів один з одним, а встановлює лише обмежений та короткий контакти 3 вчителем [4; 5; 6]. Що стосується індивідуальної навчальної роботи, то слабкі школярі все ще не встигають, тому у них значні прогалини у знаннях через відсутність умінь та навичок самостійного навчання.

Колективна форма навчання - це структура навчального процесу, в якій переважає форма організації навчання відбувається в парах, тобто дає можливість працювати колективно, і в той же час формує самостійність мислення, розвиває мову та індивідуальні здібності учнів, одночасно підвищуючи якість знань, умінь.

Протягом останніх десятиліть у педагогіці була розроблена теорія колективних способів навчання, яка втілила досвід викладача національного вченого Олександра Григоровича Ривіна. За його словами: “....початкові етапи навчання малих груп учнів особливо ефективні в технологіях пар”. 3 його допомогою можна досягти будь-якої дидактичної мети: навчання, закріплення, перевірка знань. Завдяки парній роботі всім дітям у класі надається можливість говорити та говорити. Робота в парах дає студентам можливість думати, ділитися ідеями з партнером, а потім озвучувати їх перед класом. Саме вона сприяє розвитку навичок спілкування, уміння говорити, переконувати, вести діалог, дискусію. Така співпраця не дає можливості ухилитися від виконання завдання.
Більшість уроків можна використовувати в парах:

- гра “Невідомо” (один учень читає, інший виправляє помилки);

- “Інтерв'ю” (інтерв'ю та визначення ставлення партнера до певного тексту, статті тощо);

- Гра з кішками та мишами (критично аналізувати чи редагувати написання один одного);

- "Взаємні запитання" (тестуйте та оцінюйте одне одного);

- “Щоденник з подвійною запискою” (для аналізу разом проблеми, вправи чи експерименту; сформулюйте конспект уроку чи серії уроків; відповіді на запитання вчителя).

Для організації роботи в парах використовують наступний алгоритм:

- запропонуйте учням завдання (запитання для невеликої дискусії чи аналізу ситуації).

- об'єднайте учнів у пари, визначте, хто з них буде говорити першим, і попросіть обговорити свої ідеї між собою. Краще відразу визначити час для кожної пари, щоб висловитись та обговорити разом. Це допомагає досягти згоди щодо відповіді чи рішення.

- після закінчення дискусії кожна пара представляє результати роботи, обмінюється своїми ідеями та аргументами з усім класом. При необхідності це може бути початком дискусії чи іншої пізнавальної діяльності $[8,28]$.

Співпраця в парах готує дітей до подальшої роботи в групах. Групова робота - це унікальна організація уроків, яка також успішно компенсує будь-які недоліки фронтальної та індивідуальної діяльності. Вона забезпечує взаємодію між учнями та опосередковано контролює вчителя. Він організовує початок і кінець роботи: формулює завдання, спільну інструкцію щодо його виконання разом з учнями, залученими до оцінювання результатів.

Психологи та педагоги не мають єдиного підходу до визначення групової навчальної діяльності. Ми виходимо з трактування цього як форми організації навчання в малих групах учнів, об'єднаних спільною навчальною метою в непрямих керівництві викладачів та у співпраці зі студентами $[2,8]$.

Незважаючи на ці позитивні характеристики групової діяльності, абсолютизувати їі, замінити iii на індивідуальну чи фронтальну буде великою помилкою. Порівнюючи дидактичні можливості відповідних типів навчання, виявляються сильні та слабкі сторони кожного 3 них, i підтверджується, що в реальному процесі 
навчання вони не можуть функціонувати ізольовано. 3 цієї причини ми повністю поділяємо думку спеціалістів про необхідність їх оптимальної інтеграції у навчальний процес школи.

Висновки. Досвід викладачів показав, що завдяки груповій та колективній роботівідбувається найбільший творчий розвиток особистості. Дані форми роботи мають значні переваги. На відміну від лекції, в якій переважає монологічна мова вчителя, та від самостійної роботи учнів на уроці, використовуючи групову роботу, розвиток конкретних навичок у режимі діалогу. Невеликі групи дозволяють вчителю бачити всіх у процесі практичної діяльності, сприяють появі міцних зв'язків між усіма присутніми, стимулюють процеси глибокого роздуму над діяльністю, сприяють ефективності процесу. Працюючи в колективі, діти вчаться взаємодіяти між собою, вирішувати можливі конфлікти, набувати етичних навичок міжособистісного спілкування, брати на себе відповідальність за вибір рішення, аналізувати результати діяльності. Досвід показує, що найважче самостійно розподіляти обов'язки. Важливо зазначити, що принцип тут полягає в тому, що “кожен робить те, що може зробити краще, ніж інші”. Формуванню особистості сприяє також потреба допомагати одне одному, оцінювати одне одного, критикувати, а головне відповідати за свою роботу перед собою, своєю групою та всім персоналом.

Групова та колективна діяльність - це спільна діяльність викладача та учнів, що дає можливість реалізувати природне прагнення до спілкування, взаємодопомоги та розвитку творчості. В. Сухомлинський зазначав, що “... без творчого життя не можна виховуватися, без творчості духовні, інтелектуальні, емоційні, естетичні стосунки немислимі”. Саме творчість стимулює розвиток мислення, інтересів, досліджень.

\section{ЛІТЕРАТУРА}

1. Бурлака Я. І., Вихрущ В.О. Про форми організації навчальної діяльності школярів. Рад. школа. 1984. №5. С. $39-44$.

2. Нор Е. Ф. Технологии организации групповой учебной деятельности. Николаев; 1998. 75 с.

3. Нор К. Ф., Бабаян Ю.О. Співробітництво в малих групах як засіб розвитку молодшого школяра: зб. науково-методичних вправ. Актуальні проблеми розбудови національної освіти. Херсон, 1997. С. $120-123$.

4. Педагогіка / за ред. М.Д. Ярмаченка. Київ, $1986.543 \mathrm{c}$.

5. Форми навчання в школі: книга для вчителя / за ред. Ю. І. Мальованого. Київ, 1992. 160 с.

6.Форощук А. Математика для початкових класів: навчальний посібник. Київ, 1999. 380с.

7. Черватюк С. Г., Шиманська Г.Д. Елементи цікавої математики на уроках математики. Київ, $1986.75 \mathrm{c}$.

8. Ягупов В.В. Педагогіка : навчальний посібник. Київ, 2002. 560 с.

\section{REFERENCES}

1. Burlaka,Ya. I. (1984). Pro formy orhanizatsi inavchalnoi diialnosti shkoliariv [About forms of organization of educational activity of pupils]. Kyiv, No.5, pp. 39 - 44. [in Ukrainian].

2. Hop, E. F. (1998). Tekhnolohyy orhanyzatsyy hruppovoi uchebnoi deiatelnosty shkoliariv [Technologies of organization of group educational activity]. Nykolaev, 75 p . [in Ukrainian].

3. Hop, K. F. (1997). Spivrobitnytstvo v malykh hrupakh yak zasib rozvytku molodshoho shkoliara [Collaboration in small groups as a means of developing a younger student]. Kherson, pp. 120 - 123. [in Ukrainian].

4. Yarmachenko, M.D. (1986). Pedahohika [Pedagogy]. Kyiv, 543 p. [in Ukrainian].

5. Malovanyi, Yu. I. (1992). Formy navchannia v shkoli: knyha dlia vchytelia [Forms of schooling: a book fortheteacher]. Kyiv, 160 p.[in Ukrainian].

6. Foroshchuk, A. (1999). Matematyka dlia pochatkovykh klasiv: navchalnyi posibnyk [Elementary school math: a textbook]. Kyiv, 380 p. [in Ukrainian].

7. Chervatiuk, S. H. (1986). Elementy tsikavoi matematyky na urokakh matematyky [Elements of interesting mathematics in mathematics lessons]. Kyiv, 75 p. [in Ukrainian].

8. Yahupov, V.V. (2002). Pedahohika: navchalny iposibnyk [Pedagogy: a textbook]. Kyiv, 60 p. [in Ukrainian].

Стаття надійшла до редакції 24.09.2019

\section{G58080.2058080}

“Користуйся днем, якможна менше поқладаючись на наступний".

Topaùiü

римсъкий поет

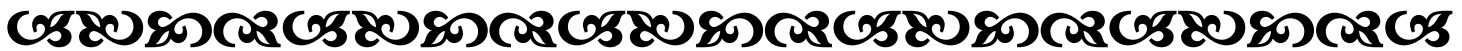

